\title{
PENGEMBANGAN SISTEM EVALUASI UNTUK DOSEN SEBAGAI UPAYA PENINGKATAN KUALITAS PEMBELAJARAN
}

\author{
Ni Ketut Kertiasih ${ }^{1}$, Komang Setemen ${ }^{2}$, Putu Hendra Suputra ${ }^{3}$, Ni Wayan Marti ${ }^{4}$ \\ Jurusan Manajemen Informatika, Fakultas Teknik Kejuruan, Universitas Pendidikan Ganesha
}

\begin{abstract}
Abstrak
Penelitian ini bertujuan untuk: 1) mengembangkan system berbasis internet dalam bentuk prototipesistem evaluasi kualitas pembelajaran berbasis web, adalah system informasi yang dikembangkan dengan mengimplementasikan Script Pemrograman PHP dengan basis data MySql 2) menyediakan aplikasi yang bertujuan untuk mempermudah dalammelakukan penilaian terhadap dosen dari segi kinerja mengajar. Sistem yang akan dikembangkan memiliki enam actor yaitu: mahasiswa, dosen, administrator, dekan, ketuajurusan dan rektor. Metode yang digunakan dalam penelitian ini mengacu pada software life cycle dengan paradigm waterfall yang meliputi 6 tahapan yaitu: 1) tahap perencanaan, 2) tahapan alisis, 3) tahap perancangan, 4) tahap pengembangan, 5) tahap pengujian, dan 6) tahap penerapan. Pengembangan sistemmeng hasilkan sebuah system berbasis web untuk memberikan evaluasi secara online oleh mahasiswa terhadap dosen terkait dengan proses pembelajaran yang dilakukan. Uji coba dilakukan oleh ahli desain dan media dengan hasil prosenta sesebesar $80,88 \%$, serta kelompok kecil mahasiswa dengan prosentase penilaian sebesar $83,93 \%$. Melalui system ini dilakukan evaluasi secara online terhadap proses pembelajaran sehingga diharapkan dapat meningkatkan kualitas pembelajaran.
\end{abstract}

Kata kunci: Sistem Informasi, Evaluasi kualitas pembelajaran, Aplikasi Berbasis Web

\begin{abstract}
This study aims to: 1 ) develop an Internet-based system in the form of a prototype system evaluating the quality of web-based learning, is an information system developed by implementing PHP Script with MySql database, 2) providing applications that aim to facilitate the assessment of the lecturer in terms of teaching performance. The system to be developed has six actors namely : students, faculty, administrators, deans, department chairman and rector. The method used in this study refers to the software life cycle with waterfall paradigm that includes six stages: 1) planning, 2) analysis phase, 3) the design phase, 4) stage of development ,5) testing, and 6) the stage of implementation. Development of the system generates a web-based system to provide online evaluations by students against lecturer associated with the learning process is done. Tests performed by design experts and the media with the results of the percentage of $80.88 \%$, and a small group of students with a percentage rating of $83.93 \%$. Through this system online evaluation of the learning process that is expected to improve the quality of learning.
\end{abstract}

Keywords: information systems, evaluation of the quality of learning , web-based applications

\section{PENDAHULUAN}

Pada dunia pendidikan, peran
dosen sebagai pengajar dalam proses
belajar mengajar di sebuah intansi
pendidikan sangatlah penting. Dosen
menjadi tumpuan dalam tranformasi ilmu yang diberikan oleh pihak instansi pendidikan kepada para mahasiswanya. Ketrampilan dan perilaku yang yang harus dimiliki, dihayati, dikuasai dan diwujudkan oleh dosen dalam melaksanakan tugas prefesional. Kompetensi dosen menentukan kualitas pelaksanaan Tridharma Pergururan 
Tinggi sebagaimana yang ditunjukan dalam kegiatan professional dosen. Untuk menjamin pelaksanaan tugas dosen berjalan sesuai dengan kreteria yang ditetapkan dalam peraturan perundang undangan maka perlu dievaluasi setiap periode waktu yang ditentukan.

Universitas Pendidikan Ganesha (Undiksha) merupakan Lembaga Pendidikan dan Tenaga Kependidikan (LPTK) selalu berupaya meningkatkan kualitas proses belajar mengajar dengan cara melakukan evaluasi terhadap dosen setiap akhir semester. Menurut Mardapi (2003)bahwa usaha peningkatan kualitas pendidikan dapat ditempuh melalui peningkatan kualitas pembelajaran dan kualitas sistem penilaian.Saat ini pengisian evaluasi terhadap dosen masih menggunakan cara manual yaitu tulis tangan dan pengolahan data menggunakanaplikasi pengolahan angka yaitu Microsoft Excel, sehinga proses pemasukan data memakan waktu dan tenaga yang banyak, hal ini disebabkan jumlah mahasiswa dan mata kuliah yang diambil cukup banyak, ini memungkinkan terjadi kesalahan dalam pemasukan data.

Evaluasi manual dengan instrumen evaluasi memiliki banyak kelemahan. Pertama, evaluasi manual memerlukan waktu dan biaya yang cukup banyak untuk memproduksi instrumennnya. Kedua, proses pemeriksaan evaluasi dengan instrumen tercetak cukup rumit, sehingga memerlukan waktu bayak dan cenderung membosankan. Ketiga, secara psikologis evaluasi manual sering menimbulkan kecemasan pada pesertates, meskipin tanpa mencantumkan identitas, namun masih dapat ditelusuri melalui pencocokan tulisan tangan.

Pada penelitianini, dicoba dikembangkan prototipe evaluasikualitas pembelajaran berbasis komputer. Fasilitas hyperteks yang dimiliki internet/intranet dilengkapi dengansistembasis-data dinamis dicoba dimanfaatkan sebagaifasilitas pendukung evaluasi.

\section{METODE PENELITIAN}

Penelitian yang dilakukan bertujuan untuk mengembangkan system evaluasi dosen.Penelitian ini menggunakan software life cycle dengan paradigm waterfall (Pressman, 2005) yang meliputi 6 tahapan yaitu: 1) tahap perencanaan, 2) tahapan alisis, 3) tahap perancangan, 4) tahap pengembangan, 5) tahap pengujian, dan 6) tahap penerapanseperti terlihat pada Gambar 1.

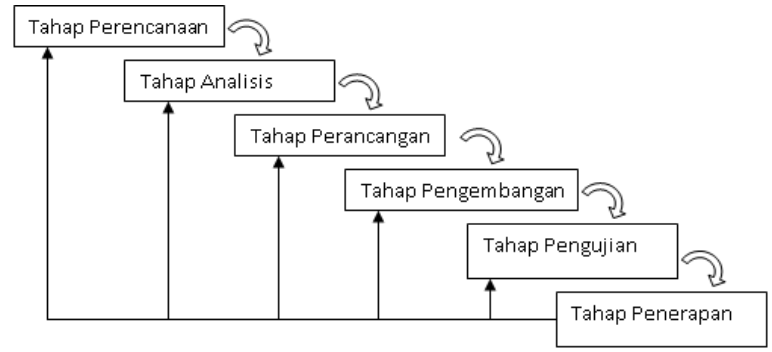

Gambar 1.Aktivitas software lifecycle dengan paradigma waterfall

Objek dalam penelitian ini adalah sistem evaluasi untuk dosen yang diisi oleh mahasiswa dan dapat diakses oleh beberapa stakeholders seperti Ketua Jurusan, Dekan, Rektor, maupun Dosen yang bersangkutan dengan user-previlege yang berbeda.

Kemudian dilakukan uji coba dan analisis data.Uji coba produk bertujuan untuk mengetahui produk yang dibuat layak digunakan atau tidak.Uji coba produk penelitian pengembangan ini terdiri atas subyek coba yaitu mahasiswa jurusan Manajemen Informatika.

Data yang diperoleh dianalisis menggunakan analisis deskriptif kualitatif dan deskriptif kuantitatif. Analisis deskriptif kualitatif digunakan untuk mengolah data hasil uji coba dari ahli desain dan media dan mahasiswa dalam uji kelompok kecil. Hasil analisis ini sebagai dasar untuk melakukan revisi. Teknik analisis ini digunakan untuk mengolah data yang diperoleh melalui angket. Hasil analisis angket dalam bentuk deskriptif persentase. 


\section{HASIL DAN PEMBAHASAN}

Proses Pengembangan prototipesistem evaluasi kualitas pembelajaran dilakukan dengan mengacu pada tahapan-tahapan yang telah disebutkan pada metode penelitian. Berdasarkan rancangan system kemudian dibuat kode programnya sehingga dihasilkan sebuah system secara online untuk melakukan memberikan evaluasi terkait dengan proses pembelajaran yang dilakukan oleh dosen sehingga diharapkanakan diperoleh pembelajaran yang berkualitas.

Berikut adalah beberapa tampilan yang dihasilkan dari pengembangan sistem evaluasi untuk dosen.

a. Tampilan Administrator

Administrator mempunyai hak akses penuh untuk mengelola sistem.Tampilan administrator seperti pada Gambar2.

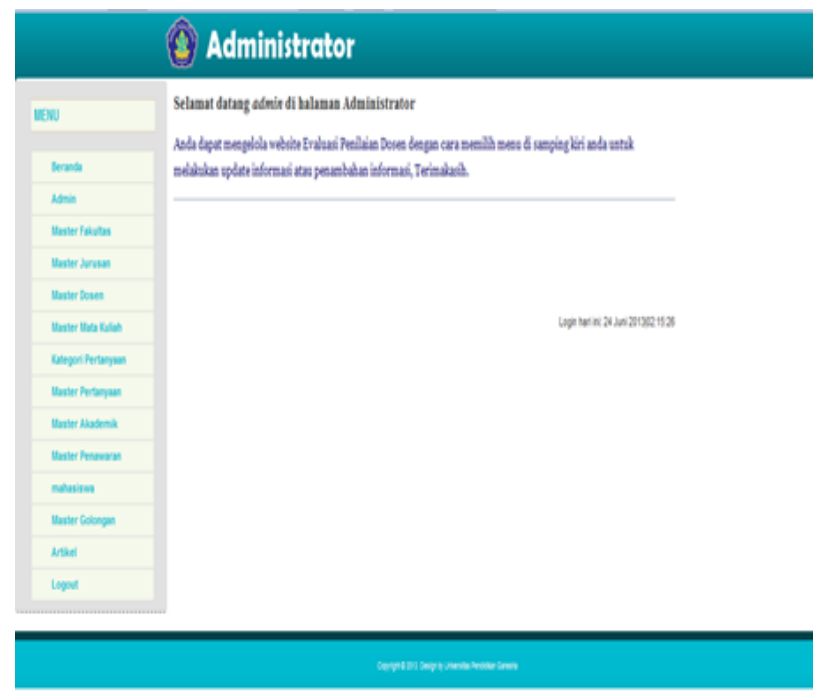

Gambar 2.Tampilan Administrator

\section{b. Tampilan Login Dosen}

Pada tampilan ini merupakan halaman login bagi dosen.Pada halaman ini memasukkan username dan password. Pada antar muka ini terdapat tiga menu utama yaitu beranda, statistic dan grafik, seperti ditampilkan pada Gambar 3.

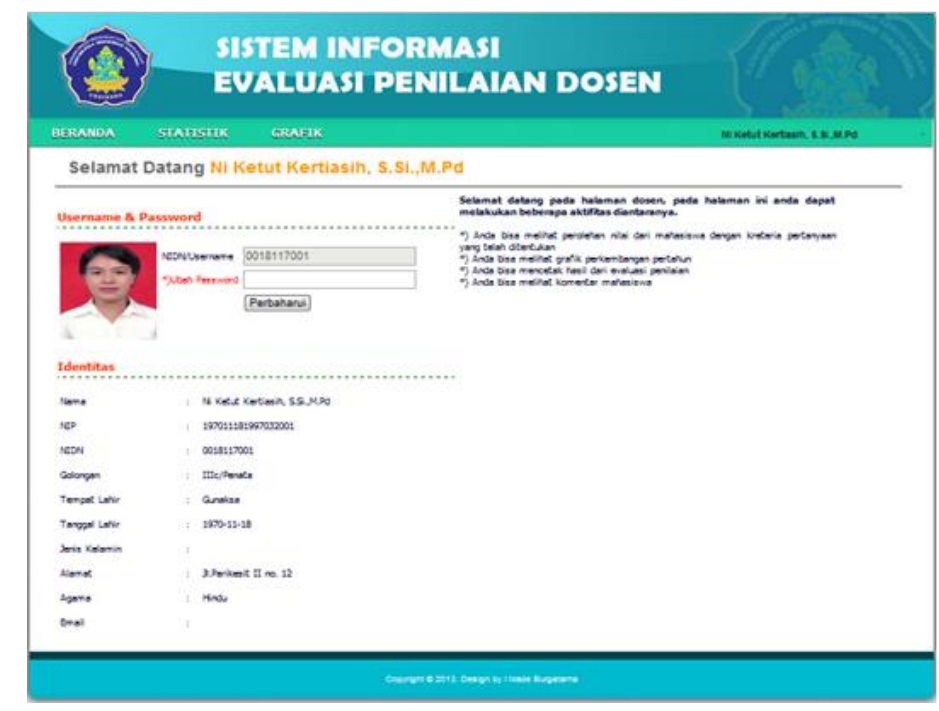

Gambar 3.Tampilan Login Dosen

c. Tampilan Hasil Evaluasi untuk Dosen

Tampilan ini untuk melihat hasil evaluasi yang diberikan oleh mahasiswa, hasilnya seperti ditampilkan pada Gambar4.

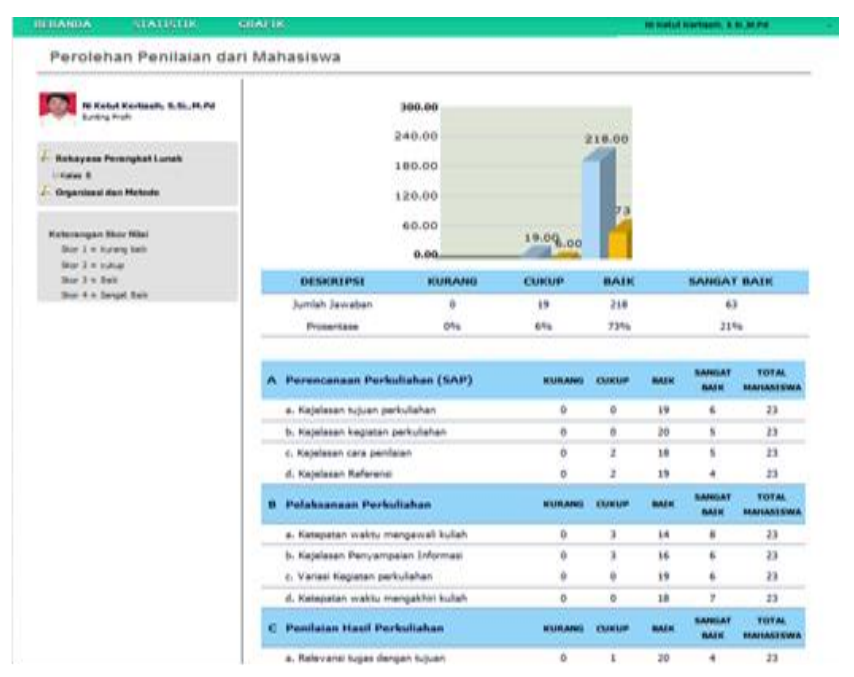

Gambar 4.Tampilan Hasil Evaluasi

d. Tampilan untuk Mahasiswa

Tampilan utama mahasiswa merupakan halaman awal yang tampil saat mahasiswa berhasil login. Tampilan tersebut seperti pada Gambar 5. 


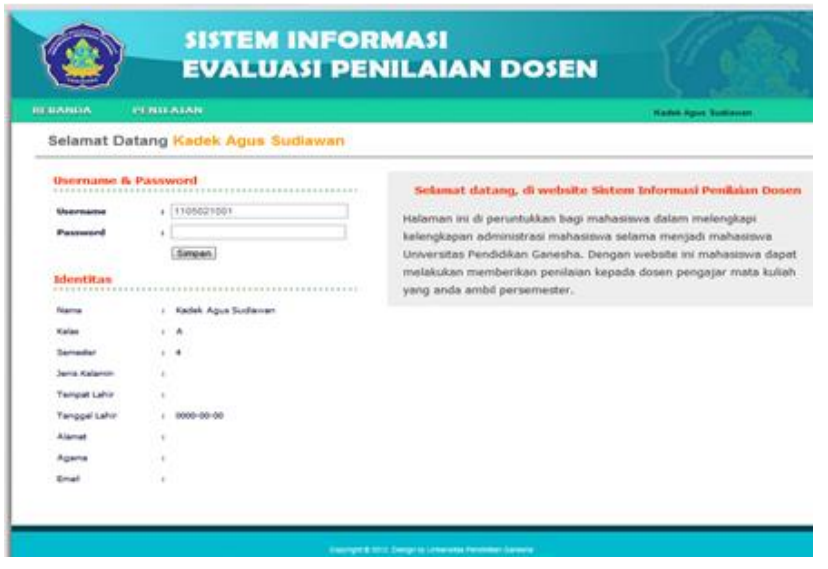

Gambar 5.Tampilan untuk Mahasiswa

Uji coba produkdilakukan oleh ahli desain dan media dan kelompok dua belas orang mahasiswa jurusan Manajemen Informatika. Hasil ujicoba diperoleh hasil penilaian ahli desain dan media diperoleh prosentase sebesar $80,88 \%$, sementara penilaian kelompok kecil mahasiswa diperoleh prosentase penilaian sebesar $83,93 \%$.

Berdasarkan hasil ujicoba yang dilakukan baik ujicoba dari ahli desain dan media maupun kelompok kecil diperoleh hasil bahwa system sesuai dengan kebutuhan yang diinginkan. Fungsi-fungsi yang ada pada sistem yang digunakan untuk mengelola data dosen, data mahasiswa, data matakuliah, data penawaran mata kuliah, data pertanyaan untuk evaluasi dosen sudah mewakili kebutuhan untuk melakukan evaluasi terhadap pembelajaran guna meningkatkan kualitas pembelajaran.

\section{PENUTUP}

Sistem evalusai untuk dosen ini dikembangkan untuk memberikan penilaian terhadap dosen secaraonline. Sistem ini dijadikan sebagai salah satu model evaluasi yang berbasis web yang digunakan untuk memberikan evaluasi terhadap proses pembelajaran yang dilakukan oleh dosen sebagai upaya untuk meningkatkan kualitas pembelajaran.

Sistem ini dapat merekapitulasi hasil penilaian terhadap dosen, dimana hasil penilaian ini nantinya dapat dijadikan sebagai acuan guna meningkatkan kinerja dosen. Penilaian yang dilakukan dapat membangun motivasi dosen untuk menjadi lebih baik dalam kinerjanya, peningkatan kinerja dapat dilihat dari penilaian mahasiswa terhadap dosen sesuai dengan pertanyaanpenilaian, yang setiap pertanyaan memiliki ketentuan.

Beberapa hal yang dapat dijadikan bahan pertimbangan untuk ditindak lanjuti guna penelitian lebih lanjut tentang pengembangan sistem diantaranya perlu dilakukan uji coba dengan jumlah responden yang lebih besar, untuk mengetahui kelemahan sistem untuk penanganan data yang lebih besar sehingga dapatdilakukan penanganan lebih lanjut.

\section{DAFTAR PUSTAKA}

Mardapi, Djemari. 2003. Desain dan Penilaian Pembelajaran Mahasiswa. Makalah disajikan dalam Lokakarya Sistem Jaminan Mutu Proses Pembelajaran, tanggal 19 Juni 2003 di Universitas Gadjah Mada Yogyakarta.

Pramudyo, Anung. 2002. "Analisis FaktorFaktor Yang Mempengaruhi Kinerja Dosen Negeri Dipekerjakan Pada Kopertis Wilayah V Yogyakarta".

TersediaPadahttp://www.portalgar 
uda.org/download_article.php?artic

$l e=9974 \& v a l=644$

Pressman, Roger S, 2005, Software engineering: a practitioner's approach (sixth edition). R.S. Pressman\& Associates, Inc 
JPTK, UNDIKSHA, Vol. 12, No. 1, Januari 2015 : 27-34 